\title{
ANALISIS BERPIKIR KREATIF SISWA DALAM \\ MEMECAHKAN MASALAH MATEMATIKA \\ BERDASARKAN TIPE KEPRIBADIAN
}

\author{
${ }^{1}$ Linda Indiyarti Putri, ${ }^{2}$ Lia Ismawati \\ 1lindaputri5@gmail.com, 2 liaciemuetchan14@gmail.com \\ ${ }^{1,2}$ Universitas Wahid Hasyim Semarang
}

\begin{abstract}
ABSTRAK
Kenyataan menunjukkan bahwa masih banyak siswa yang kesulitan dalam menyelesaikan permasalahan dalam pembelajaran matematika. Hal ini menjadi masalah mendasar yang berdampak langsung pada prestasi akademik siswa. Berhasil tidaknya kesuksesan seorang siswa tidak semata-mata bergantung pada kecerdasan kognitif saja, tetapi juga dipengaruhi oleh dimensi kepribadian mereka. Penelitian lapangan kualitatif ini mengambil fokus penelitian mencari pola bagaimana kemampuan berpikir kreatif dalam memecahkan masalah matematika ditinjau dari tipe kepribadian peserta didik MI Yasua Pilangwetan Kecamatan Kebonagung Kabupaten Demak. Tujuannya adalah mencari dan mendeskripsikan kemampuan berpikir kreatif peserta didik. Hasil penelitian menunjukkan kemampuan berpikir kreatif dalam memecahkan masalah matematika meliputi tipe kepribadian: (1) Artisan; (2) Guardian; (3) Idealist; (4) Rational. Hasil analisis menyatakan bahwa subjek dengan tipe kepribadian Rational yang memiliki kemampuan berpikir kreatif dalam memecahkan masalah matematika lebih tinggi dari tipe kepribadian yang lain karena Rational memenuhi keempat aspek kemampuan berpikir kreatif dalam memecahkan masalah matematika.
\end{abstract}

Kata Kunci: Berpikir Kreatif, Matematika, Tipe Kepribadian

\section{PENDAHULUAN}

Pendidikan nasional berfungsi mengembangkan kemampuan dan membentuk watak serta peradaban bangsa yang bermartabat dalam rangka mencerdaskan kehidupan bangsa, bertujuan untuk berkembangnya potensi peserta didik agar menjadi manusia yang beriman dan bertakwa kepada Tuhan Yang Maha Esa, berakhlak mulia, sehat, berilmu, cakap, kreatif, mandiri, dan menjadi warga negara yang demokratis serta bertanggungjawab (Undang-undang Republik Indonesia Nomor 20 Tahun 2003 tentang Sitem Pendidikan Nasional, 2003:3-24). Sedangkan menurut Ibnu Sina yang dikutip oleh Mudzakir Ali dalam al-Zantany pendidikan adalah (Mudzakir Ali, 2012:8-9.): 


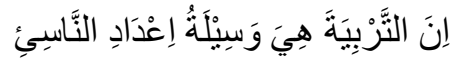

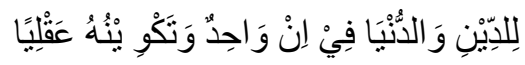

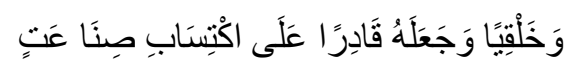

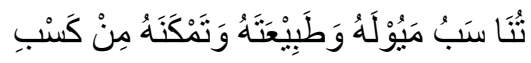

$$
\begin{aligned}
& \text { عَيْنِيه }
\end{aligned}
$$

Artinya: sesungguhnya pendidikan adalah sarana mempersiapkan orang yang sedang tumbuh (generasi) untuk agama dan dunia di dalam suatu keadaan dan membentuknya (agar bepikir) rasional dan berakhlak dan menjadikannya memiliki kemampuan untuk berusaha produktif sesuai dengan minat dan bakatnya yang memungkinkan terpenuhinya kebutuhan hidupnya.

Permasalahan pendidikan saat ini terutama pada pembelajaran matematika adalah rendahnya kemampuan peserta didik dalam memecahkan masalah. Hal ini disebabkan salah satunya karena kelemahan peserta didik dalam aspekaspek kemampuan berpikir kreatif yang diperlukan dalam memecahkan masalah. Mata pelajaran matematika merupakan salah satu kurikulum pendidikan dasar dan menengah wajib. Mata pelajaran matematika perlu diberikan kepada semua peserta didik mulai dari sekolah dasar untuk membekali peserta didik dengan kemampuan berpikir logis, analisis, sistematis, kritis, dan kreatif, serta kemampuan belajar sama (Undangundang Republik Indonesia Nomor 20 Tahun 2003 tentang Sitem Pendidikan Nasional, 2003:10-11). tetapi berdasarkan pada observasi peneliti lakukan pada saat proses belajar mengajar berlangsung dan pada hasil nilai ulangan harian matematika semester ganjil, peserta didik siswi MI khususnya di kelas IV MI Yasua Pilangwetan dalam kemampuan berpikir kreatif dalam memecahkan masalah soal matematika masih tergolong rendah, karena banyak dari mereka masih belum paham apa yang disampaikan oleh guru.

Memecahkan masalah menurut Permendiknas No. 22 tahun 2006 yaitu meliputi kemampuan memahami masalah, merancang model matematika, menyelesaikan model dan menafsirkan solusi yang diperoleh (Linda Wijaya, 2015:6). Memahami maupun merencanakan penyelesaian masalah diperlukan suatu kemampuan berpikir kreatif peserta didik yang 
memadai, karena kemampuan tersebut merupakan kemampuan berpikir tingkat tinggi setelah bepikir dasar dan kiritis, hal ini dikemukakan Krulik sebagaimana dikutip oleh Siswono dalam Linda Wijaya. Didukung oleh Silver sebagaimana yang dikutip oleh Tatang Yuli Eko Siswono menjelaskan untuk menilai berpikir kreatif siswa menggunakan acuan yang meliputi kefasihan (fluency), fleksibilitas dan kebaruan (novelty). Kefasihan mengacu pada banyaknya ide-ide yang dibuat dalam merespon sebuah perintah. Fleksibilitas tampak pada perubahan-perubahan pendekatan ketika merespons perintah. Kebaruan merupakan keaslian ide yang dibuat dalam merespons perintah (Tatang, 2005:4.).

Sedangkan menurut Feist sebagaimana yang dikutip oleh Yan, Childs, Hall dalam Linda Wijaya menunjukan kreatifitas atau berpikir kreatif dalam individu bergantung pada beberpa komponen, seperti kemampuan kognitif dan faktor kepribadian. Kepribadian kreatif ada ciri-ciri kepribadian yang abadi dan relatif stabil dari waktu ke waktu, yang diwujudkan dalam perilaku kreatif dan mempengaruhi pemikiran kreatif, yang menunjuk ke kemungkinan kinerja kreatif, disposisi kepribadian lakukan teratur dan diduga berhubungan dengan pencapaian kreatif. Sebuah alternatif untuk ciri kepribadian adalah tipe kepribadian (Linda Wijaya, 2015:7).

Menurut

Keirsey menggolongkan kepribadian menjadi 4 tipe, yaitu Artisan, Guardian, Idealist, Rational. Penggolongan yang dilakukan oleh Keirsey ini berdasarkan perilaku manusia. Setiap orang mempunyai karakteristik, bakat dan lain-lain yang berbeda-beda (David Keirsey, 1998:31). Menurut Munandar sebagaimana yang dikutip oleh Linda Wijaya, setiap orang mempunyai bakat dan kemampuan yang berbeda-beda dan karena itu membutuhkan pendidikan yang berbeda-beda pula. Menurut Hamalik sebagaimana yang dikutip oleh Linda Wijaya, untuk memahami kemampuan yang berbedabeda dari peserta didik, guru perlu mengenal sifat-sifat kepribadian murid agar guru mudah mengadakan pendekatan pribadi dengan mereka, guru dapat pula menyediakan kegiatan-kegiatan yang serasi dengan 
kepribadian mereka dan memelihara sifat-sifat yang baik serta sedapat mungkin mengurangi sifat-sifat yang jelek (Linda Wijaya, 2016:7). Setelah mengetahui dan memahami masingmasing peserta didik, diharapkan pengajar dapat menerapkan metode mengajar yang sesuai dengan kepribadian setiap peserta didik (Wakhid, 2015:36 ).

Berdasarkan uraian tersebut, penelitian yang berjudul analisis berpikir kreatif dalam memecahkan masalah matematika ditinjau dari tipe kepribadian peserta didik menjadi sangat perlu untuk dilakukan. Adapun tipe kepribadian yang digunakan dalam poin penelitian ini antara lain artisan, guardian, idealist, dan rational.

\section{METODE PENELITIAN}

Penelitian ini difokuskan pada mencari pola bagaimana kemampuan berpikir kreatif dalam memecahkan masalah matematika ditinjau dari tipe kepribadian peserta didik MI Yasua Pilangwetan Kecamatan Kebonagung Kabupaten Demak. Tujuan Penelitian ini adalah untuk mencari dan mendeskripsikan kemampuan berpikir kreatif peserta didik kelas IV di MI
Yasua Pilangwetan Kecamatan Kebonagung Kabupaten Demak, dalam memecahkan masalah matematika ditinjau dari tipe kepribadian artisan, guardian, idealist, dan rational.

Jenis penelitian ini adalah deskriptif kualitatif. Penelitian dilaksanakan di MI Yasua Pilangwetan Kecamatan Kebonagung, Kabupaten Demak pada bulan desember tahun 2017 sampai maret 2018. Subjek penelitian ini adalah 8 peserta didik kelas IV MI Yasua Pilangwetan Kebonagung Demak. Pemilihan subjek didasarkan pada penggolongan tipe kepribadian peserta didik menurut Keirsey yaitu artisan, guardian, idealist, dan rational.

Hasil penggolongan mengemukakan bahwa terdiri 6 peserta didik tergolong tipe artisan, 6 peserta didik tergolong tipe guardian, 8 peserta didik tergolong tipe idealist, dan 6 peserta didik tergolong09o tipe rational. Berdasarkan hasil penggolongan tipe kepribadian, peneliti memlilih 2 peserta didik dari masing-masing tipe kepribadian, yaitu 2 peserta didik artisan, 2 peserta didik guardian, 2 peserta didik idealist, dan 
2 peserta didik rational. Berikut subjek penelitian terpilih untuk dideskripsikan kemampuan berpikir kreatif dalam memecahkan masalah matematika ditinjau dari tipe kepribadian yang ditampilkan pada Tabel 1 sebagai berikut:

Tabel 1. Subjek Penelitian Terpilih

\begin{tabular}{cccc}
\hline No & Kode Siswa & Tipe Kepribadian & Kode Subjek \\
\hline 1 & IV-7 & Artisan & AR-1 \\
2 & IV-11 & Artisan & AR-2 \\
3 & IV-4 & Guardian & GU-1 \\
4 & IV-48 & Guardian & GU-2 \\
5 & IV-6 & Idealist & ID-1 \\
6 & IV-22 & Idealist & ID-2 \\
7 & IV-13 & Rational & RA-1 \\
8 & IV-20 & Rational & RA-2 \\
\hline
\end{tabular}

Metode pengumpulan data pada penelitian ini adalah observasi, tes penggolongan tipe kepribadian menurut Keirsey, tes kemampuan berpikir kreatif matematika, wawancara, dan dokumentasi. Metode analisis data pada penelitian ini meliputi langkah reduksi data, penyajian data, dan penarikan simpulan dan verivikasi. Analisis hasil penelitian pada kemampuan berpikir kreatif dalam memecahkan masalah matematika siswa kelas IV mengacu pada hasil tes kemampuan berpikir kreatif matematikadan wawancara yang berdasarkan aspek kelancaran, keluwesan, keaslian, dan elaborasi.

\section{Peneliti}

melakukan pemeriksaan keabsahan data dengan menggunakan teknik triangulasi yang memanfaatkan penggunaan sumber. Penelitian ini dilakukan dengan ajalan membandingkan hasil tes kemampuan berpikir kreatif matematika dengan hasil wawancara dari sebjek penelitian untuk memperoleh deskripsi kemampuan berpikir kreatif dalam memecahkan masalah matematika siswa artisan, guardian, idealist, dan rational.

\section{HASIL DAN ANALISIS PENELITIAN \\ Berdasarkan pada tes penggolongan tipe kepribadiandam}


hasil wawancara, peneliti melakukan pemilihan subjek, setelah dilakukan pemilihan subjek, peneliti melaksanakan kegiatan tes kemampuan berpikir kreatif matematika dan wawancara untuk memperoleh pola dan deskripsi kemampuan berpikir kreatif dalam memecahkan masalah matematika siswa. Tes dan wawancara dianalisis dengan memperhatkan 4 aspek kemampuan berpikir kreatif matematika yaitu, kelancaran, keluwesan keaslian, dan elaborasi.

Kelancaran mengacu pada kemampuan menjawab masalah matematika sesuai dengan prosedur pengerjaan dan menghasilkan jawaban yang benar. Keluwesan mengacu pada kemampuan menjawab masalah matematika melalui cara yang bervariasi. Bisa satu permasalahan dengan banyak jawaban atau satu jawaban dengan banyak cara. Keaslian mengacu pada kemampuan menjawab masalah matematika dengan menggunakan bahasa, cara, atau ide sendiri. Elaborasi mengacu pada kemampuan mengembangkan, memperluas jawaban masalah, menambah masalah baru atau gagasan dan memperinci detail-detail.

Tes kemampuan berpikir kreatif matematika terdiri dari 8 soal yaitu: soal nomor 1.a (S1), soal nomor 1.b (S2), soal nomor 2 (S3), soal nomor 3 (S4), soal nomor 4.a (S5), soal nomor 4.b (S6), soal nomor 5.a (S7), dan soal nomor 5.b (S8). Soal yang termasuk dalam aspek kelancaran yaitu S1, S2, S3, S6, dan S7. Soal yang termasuk dalam aspek keluwesan dan keaslian yaitu S4 dan S8. Soal yang termasuk dalam aspek elaborasi yaitu S5. Peneliti dalam menentukan hasil tes kemampuan berpikir kreatif matematika yang diperoleh peserta didik pada setiap aspek kemampuan berpikir kreatif matematika dengan cara mencari rata-rata dan menggunakan kriteria sebagai berikut:

Tabel 2. Kriteria Kemampuan Berpikir Kreatif Matematika

\begin{tabular}{cc}
\hline Skor & Keterangan \\
\hline $0 \leq \bar{x} \leq 1$ & Tidak Baik \\
$1 \leq \bar{x} \leq 2$ & Kurang Baik \\
$2 \leq \bar{x} \leq 3$ & Cukup Baik \\
$3 \leq \bar{x} \leq 4$ & Baik \\
$4 \leq \bar{x} \leq 5$ & Sangat Baik \\
\hline
\end{tabular}


Keterangan:

$\bar{x} \quad=$ rata-rata dari skor yang

diperoleh pada aspek

kelancaran, atau keluwesan

atau keaslian atau elaborasi.
Hasil ketercapaian masingmasing aspek oleh subjek penelitian pada kegiatan tes kemampuan berpikir kreatif matematika dan wawancara, serta triangulasi maka akan tampilkan pada Tabel 2 berikut:

Tabel 3. Kemampuan Berpikir Kreatif dalam Memecahkan Masalah Matematika Ditinjau dari Tipe Kepribadian

\begin{tabular}{|c|c|c|c|c|c|}
\hline \multirow{2}{*}{ No } & \multirow{2}{*}{ Subjek } & \multicolumn{4}{|c|}{ Aspek Kemampuan Berpikir Kreatif } \\
\cline { 3 - 6 } & & Kelancaran & Keluwesan & Keaslian & Elaborasi \\
\hline 1 & AR-1 & Cukup Baik & Tidak Baik & Kurang Baik & Baik \\
2 & AR-2 & Cukup Baik & Tidak Baik & Kurang Baik & Baik \\
3 & GU-1 & Kurang Baik & Tidak Baik & Tidak Baik & Kurang Baik \\
4 & GU-2 & Kurang Baik & Tidak Baik & Tidak Baik & Kurang Baik \\
5 & ID-2 & Sangat Baik & Tidak Baik & Cukup Baik & Cukup Baik \\
6 & ID-2 & Baik & Tidak Baik & Kurang Baik & Cukup Baik \\
7 & RA-1 & Sangat Baik & Sangat Baik & Sangat Baik & Sangat Baik \\
8 & RA-2 & Sangat Baik & Sangat Baik & Sangat Baik & Sangat Baik \\
\hline
\end{tabular}

\section{a. Kemampuan Berpikir Kreatif} dalam Memecahkan Masalah Matematika Tipe Artisan

Hasil analisis berpikir kreatif dalam memecahkan masalah matematika siswa ditinjau dari tipe kepribadian Artisan. Pertama, aspek kelancaran yaitu berdasarkan hasil tes dan wawancara pada kemampuan berpikir kreatif dalam memecahkan masalah matematika pada subjek AR-1 terindentifikasi memperoleh skor 3, 3, 4, 1 dan 1 pada soal $\mathrm{S} 1$, S2, S3, S6, dan S7. Sedangkan subjek AR-2 terindentifikasi memperoleh skor 5, 4, 3, 0 dan 3 pada soal S1, S2, S3, S6, dan S7. Subjek AR-2 hanya memenuhi aspek kelancaran pada satu soal dari 5 soal, serta skor rata-rata kemampuan berpikir kreatif matematika AR-1 dan AR-2 adalah 2,4 dan 3 sehingga kemampuan berpikir kreatif dalam memecahkan masalah matematika tipe artisan pada aspek kelancaran yaitu cenderung cukup baik, jadi secara umum dapat disimpulkan bahwa tipe artisan tidak memenuhi aspek kelancaran. 
Kedua, Aspek keluwesan diperoleh bahwa AR-1 dan AR-2 terindentifikasi memperoleh skor 1 dan 0 pada soal S4 dan S8. Subjek AR-1 dan AR-2 tidak ada yang memenuhi aspek keluwesan pada kedua soal tersebut, serta skor rata-rata kemampuan berpikir kreatif matematika AR-1 dan AR1 pada aspek keluwesan yaitu masing-masing $0,5, \quad$ sehingga kemampuan berpikir kreatif dalam memecahkan masalah matematika tipe artisan pada aspek keluwesan yaitu cenderung tidak baik. Secara umum dapat disimpulkan bahwa tipe artisan tidak memenuhi aspek keluwesan.

Ketiga, aspek keaslian diperoleh bahwa subjek AR-1 terindentifikasi memperoleh skor 2 dan 0 pada soal S4 dan S8. Sedangkan subjek AR-2 terindentifikasi memperoleh skor 3 dan 0 pada soal S4 dan S8. subjek AR-1 dan AR-2 tidak ada yang memenuhi aspek kealian dari kedua soal, serta skor rata-rata kemampuan berpikir kreatif matematika subjek AR-1 dan AR2 adalah 1 dan 1,5 sehingga kemampuan berpikir kreatif dalam memecahkan masalah matematika tipe artisan pada aspek keaslian yaitu cenderung kurang baik. Secara umum dapat disimpulkan bahwa tipe artisan tidak memenuhi aspek keaslian.

Keempat, Aspek elaborasi diperoleh bahwa subjek AR-1 terindentifikasi memperoleh skor 3 pada soal S5. Sedangkan subjek AR-2 terindentifikasi memperoleh skor 4 pada soal S5. subjek AR-1 dan AR-2 tidak ada yang memenuhi aspek elaborasi dari soal, serta skor rata-rata kemampuan berpikir kreatif matematika subjek AR-1 dan AR-2 adalah 3 dan 4, sehingga kemampuan berpikir kreatif dalam memecahkan masalah matematika tipe artisan pada aspek elaborasi yaitu cenderung baik, jadi secara umum dapat disimpulkan bahwa tipe artisan tidak memenuhi aspek elaborasi.

Berdasarkan hasil analisis di atas, subjek AR-1 dan AR-2 diperoleh bahwa kemampuan berpikir kreatif dalam memecahkan masalah matematika 
pada aspek kelancaran, keluwesan, keaslian, dan elaborasi yaitu cenderung cukup baik, tidak baik, kurang baik dan baik, sehingga siswa dengan tipe artisan tidak memenuhi keempat aspek kemampuan berpikir kreatif dalam memecahkan masalah matematika.

\section{a. Kemampuan Berpikir Kreatif} dalam Memecahkan Masalah Matematika Tipe Guardian

Hasil analisis berpikir
kreatif dalam memecahkan
masalah matematika siswa ditinjau
dari tipe kepribadian guardian.
Pertama, Aspek kelancaran yaitu
berdasarkan hasil tes dan
wawancara pada kemampuan
berpikir kreatif dalam
memecahkan masalah matematika
pada subjek GU-1 terindentifikasi
memperoleh skor 3, 1, 1, 1 dan 0
pada soal S1, S2, S3, S6, dan S7.
Sedangkan subjek GU-2
terindentifikasi memperoleh skor
3, 1, 3, 1 dan 0 pada soal S1, S2,
S3, S6, dan S7. Subjek GU-1 dan
GU-2 tidak ada yang memenuhi
aspek kelancaran pada kelima
soal, serta skor rata-rata

kemampuan berpikir kreatif matematika GU-1 dan GU-2 adalah 1,2 dan 1,6 sehingga kemampuan berpikir kreatif dalam memecahkan masalah matematika tipe guardian pada aspek kelancaran yaitu cenderung kurang baik. Secara umum dapat disimpulkan bahwa tipe guardian tidak memenuhi aspek kelancaran.

Kedua, Aspek keluwesan yaitu berdasarkan hasil tes dan wawancara pada kemampuan berpikir kreatif dalam memecahkan masalah matematika pada subjek GU-1 terindentifikasi memperoleh skor 1 dan 0 pada soal S4 dan S8. Sedangkan subjek GU-2 terindentifikasi memperoleh skor 2 dan 0 pada soal S4 dan S8. Subjek GU-1 dan GU-2 tidak ada yang memenuhi aspek kelancaran pada kedua soal, serta skor ratarata kemampuan berpikir kreatif matematika GU-1 dan GU-2 adalah 0,5 dan 1 sehingga kemampuan berpikir kreatif dalam memecahkan masalah matematika tipe guardian pada aspek keluwesan yaitu cenderung kurang tidak baik, karena skor rata-rata 
subjek GU-2 mendekati tidak baik, jadi secara umum dapat disimpulkan bahwa tipe guardian tidak memenuhi aspek keluwesan.

Ketiga, Aspek keaslian diperoleh bahwa subjek GU-1 dan GU-2 terindentifikasi memperoleh skor 1 dan 0 pada soal S4 dan S8. subjek GU-1 dan GU-2 tidak ada yang memenuhi aspek kealian dari kedua soal, serta skor rata-rata kemampuan berpikir kreatif matematika subjek GU-1 dan GU2 adalah 0,5 sehingga kemampuan berpikir kreatif dalam memecahkan masalah matematika tipe guardian pada aspek keaslian yaitu cenderung tidak baik. Secara umum dapat disimpulkan bahwa tipe guardian tidak memenuhi aspek keaslian.

Keempat, aspek elaborasi diperoleh bahwa subjek GU-1 dan GU-2 terindentifikasi memperoleh skor 1 pada soal S5. subjek GU-1 dan GU-2 tidak ada yang memenuhi aspek kealian dari kedua soal, serta skor rata-rata kemampuan berpikir kreatif matematika subjek GU-1 dan GU2 adalah 1 sehingga kemampuan berpikir kreatif dalam memecahkan masalah matematika tipe guardian pada aspek elaborasi yaitu cenderung kurang baik. Secara umum dapat disimpulkan bahwa tipe guardian tidak memenuhi aspek elaborasi.

Berdasarkan hasil analisis di atas, subjek GU-1 dan GU-2 diperoleh bahwa kemampuan berpikir kreatif dalam memecahkan masalah matematika pada aspek kelancaran, keluwesan, keaslian, dan elaborasi yaitu cenderung kurang baik, tidak baik, tidak baik dan kurang baik, sehingga siswa dengan tipe guardian tidak memenuhi keempat aspek kemampuan berpikir kreatif dalam memecahkan masalah matematika.

b. Kemampuan Berpikir Kreatif dalam Memecahkan Masalah Matematika Tipe Idealist

Hasil analisis berpikir
kreatif dalam memecahkan
masalah matematika siswa ditinjau
dari tipe kepribadian idealist.
Pertama, aspek kelancaran yaitu
berdasarkan hasil tes dan


wawancara pada kemampuan berpikir kreatif dalam memecahkan masalah matematika pada subjek ID-1 terindentifikasi memperoleh skor 5, 3, 5, 5 dan 3 pada soal S1, S2, S3, S6, dan S7. Sedangkan subjek ID-2 terindentifikasi memperoleh skor 5, 3, 3, 2 dan 3 pada soal S1, S2, S3, S6, dan S7. Subjek ID-1 hanya memenuhi 3 aspek kelancaran pada kelima soal. Sedangkan subjek ID-2 hanya memenuhi 1 aspek kelancaran pada kelima soal, serta skor rata-rata kemampuan berpikir kreatif matematika ID-1 dan ID-2 adalah 4,2 dan 3,2 sehingga kemampuan berpikir kreatif dalam memecahkan masalah matematika tipe idealist pada aspek kelancaran yaitu cenderung baik, karena subjek ID-2 mendekati baik, jadi secara umum dapat disimpulkan bahwa tipe idealist tidak memenuhi aspek kelancaran.

Kedua, aspek keluwesan diperoleh bahwa subjek ID-1 terindentifikasi memperoleh skor 2 dan 0 pada soal S4 dan S8. Sedangkan subjek ID-2 terindentifikasi memperoleh skor 1 dan 0 pada soal S4 dan S8. Subjek ID-1 dan ID-2 tidak ada yang memenuhi aspek keluwesan dari kedua soal tersebut, serta skor rata-rata kemampuan berpikir kreatif matematika ID-1 dan ID-2 adalah 1 dan 0,5 sehingga kemampuan berpikir kreatif dalam memecahkan masalah matematika tipe idealist pada aspek keluwesan yaitu tidak baik, jadi secara umum dapat disimpulkan bahwa tipe idealist tidak memenuhi aspek keluwesan.

Ketiga, aspek keaslian diperoleh bahwa subjek ID-1 terindentifikasi memperoleh skor 5 dan 0 pada soal S4 dan S8. Sedangkan subjek ID-2 terindentifikasi memperoleh skor 2 dan 0 pada soal S4 dan S8. Subjek ID-1 hanya memenuhi 1 aspek keaslian dari kedua soal. Sedangkan ID-2 tidak ada yang memenuhi aspek keluwesan dari kedua soal tersebut, serta skor rata-rata kemampuan berpikir kreatif matematika ID-1 dan ID-2 adalah $\quad 2,5$ dan 1 sehingga kemampuan berpikir kreatif dalam 
memecahkan masalah matematika tipe idealist pada aspek keaslian yaitu kurang baik, karena subjek ID-1 dan ID-2 mendekati cenderung kurang baik, jadi secara umum dapat disimpulkan bahwa tipe idealist tidak memenuhi aspek keaslian.

Keempat, Aspek elaborasi diperoleh bahwa subjek ID-1 dan ID-2 terindentifikasi memperoleh skor 3 pada soal S5. Subjek ID-1 dan ID-2 tidak ada yang memenuhi aspek keluwesan dari kedua soal tersebut, serta skor rata-rata kemampuan berpikir kreatif matematika ID-1 dan ID-2 adalah masing-masing 3 , sehingga kemampuan berpikir kreatif dalam memecahkan masalah matematika tipe idealist pada aspek elaborasi yaitu cukup baik, jadi secara umum dapat disimpulkan bahwa tipe idealist tidak memenuhi aspek elaborasi.

Berdasarkan hasil analisis di atas, subjek ID-1 dan ID-2 diperoleh bahwa kemampuan berpikir kreatif dalam memecahkan masalah matematika pada aspek kelancaran, keluwesan, keaslian, dan elaborasi yaitu cenderung baik, tidak baik, kurang baik dan cukup baik, sehingga siswa dengan tipe idealist tidak memenuhi keempat aspek kemampuan berpikir kreatif dalam memecahkan masalah matematika.

c. Kemampuan Berpikir Kreatif dalam Memecahkan Masalah Matematika Tipe Rational

Hasil analisis berpikir kreatif dalam memecahkan masalah matematika siswa ditinjau dari tipe kepribadian rational. Pertama, Aspek kelancaran yaitu berdasarkan hasil tes dan wawancara pada kemampuan berpikir kreatif dalam memecahkan masalah matematika pada subjek RA-1 terindentifikasi memperoleh skor $4,5,4,5$ dan 5 pada soal S1, S2, S3, S6, dan S7. Sedangkan subjek RA-2 terindentifikasi memperoleh skor 5, 5, 4, 5 dan 5 pada soal S1, S2, S3, S6, dan S7. Subjek RA-1 hanya memenuhi 3 aspek kelancaran pada kelima soal. Sedangkan subjek RA-2 hanya memenuhi 4 aspek kelancaran 
pada kelima soal, serta skor ratarata kemampuan berpikir kreatif matematika RA-1 dan RA-2 adalah 4,6 dan 4,8 sehingga kemampuan berpikir kreatif dalam memecahkan masalah matematika tipe rational pada aspek kelancaran yaitu cenderung sangat baik, jadi secara umum dapat disimpulkan bahwa tipe rational memenuhi aspek kelancaran.

Kedua, aspek keluwesan diperoleh bahwa subjek RA-1 terindentifikasi memperoleh skor 4 dan 5 pada soal S4 dan S8. Sedangkan subjek RA-2 terindentifikasi memperoleh skor 5 dan 4 pada soal S4 dan S8. Subjek RA-1 dan RA-2 hanya memenuhi 1 aspek keluwesan dari kedua soal tersebut, serta skor rata-rata kemampuan berpikir kreatif matematika RA-1 dan RA2 adalah masing-masing 4,5 sehingga kemampuan berpikir kreatif dalam memecahkan masalah matematika tipe rational pada aspek keluwesan yaitu sangat baik. Secara umum dapat disimpulkan bahwa tipe rational memenuhi aspek keluwesan.
Ketiga, Aspek keaslian diperoleh bahwa subjek RA-1 dan RA-2 terindentifikasi memperoleh skor 5 dan 5 pada soal S4 dan S8. Subjek RA-1 dan RA-2 memenuhi semua aspek keaslian dari kedua soal tersebut, serta skor rata-rata kemampuan berpikir kreatif matematika RA-1 dan RA-2 adalah masing-masing 5 , sehingga kemampuan berpikir kreatif dalam memecahkan masalah matematika tipe rational pada aspek keaslian yaitu sangat baik. Secara umum dapat disimpulkan bahwa tipe rational memenuhi aspek keaslian.

Keempat, aspek elaborasi diperoleh bahwa subjek RA-1 dan RA-2 terindentifikasi memperoleh skor 5 pada soal S5. Subjek RA-1 dan RA-2 memenuhi semua aspek elaborasi dari soal tersebut, serta skor rata-rata kemampuan berpikir kreatif matematika RA-1 dan RA2 adalah masing-masing 5, sehingga kemampuan berpikir kreatif dalam memecahkan masalah matematika tipe rational pada aspek elaborasi yaitu sangat baik. Secara umum dapat 
disimpulkan bahwa tipe rational memenuhi aspek elaborasi.

Berdasarkan hasil analisis di atas, subjek RA-1 dan RA-2 diperoleh bahwa kemampuan berpikir kreatif dalam memecahkan masalah matematika pada aspek kelancaran, keluwesan, keaslian, dan elaborasi yaitu masing-masing cenderung sangat baik, sehingga siswa dengan tipe rational memenuhi keempat aspek kemampuan berpikir kreatif dalam memecahkan masalah matematika. Berdasarkan hasil penelitian, kemampuan berpikir kreatif dalam ememcagkan masalah matematika ditinjau dari tipe kepriadian siswa yang bertipe kepribadian rational mempunyai kemampuan berpikir kreatif dalam memecahkan masalah matematika lebih tinggi dari pada siswa yang bertipe kepribadian artisan, guardian, dan idealist pada aspek kelancaran, keluwesan, keaslian, dan elaborasi. Hal ini didukung oleh Aries Yuwono mengemukakan bahwa siswa bertipe rational dapat menyelesaikan

pemecahan

masalah dengan benar dan lancar. Pernyataan ini juga dipertegas oleh M.J. Dewiyani S. yang menyatakan bahwa tipe rational lebih menyukai mata pelajaran sains atau matematika walaupun tidak menutup kemungkinan tipe rational unggul dibidang mata pelajaran lainnya, tetapi penelitian ini juga menyangkal pernyataan Yan, Childs dan Hall yang duikutip oleh Linda Wijaya menyatakan bahwa jumlah idealist dan rational hanya sebagian kecil dari populasi, karena dalam penelitian ini ditemukan bahwa dalam kelas IV MI Yasua Pilangwetan terdapat 27 siswa dan yang bertipe kepribadian idealist 8 dan rational 6.

Jumlah siswa yang bertipe rational sebanding dengan siswa yang bertipe kepribadian artisan dan guardian, serta penelitian ini menyangkal penyataan Yan, Childs, dan Hall yang dikutip oleh Linda Wijaya yaitu tipe kepribadian idealist yang berpotensi kreatif. Ternyata dalam 
penelitian ini pada kemampuan berpikir kreatif dalam memecahkan masalah matematika dengan aspek kelancaran, keluwesan, keaslian, dan elaborasi tipe artisan dan idealist hampir sama, tetapi pada pernyataan Yan, Childs, dan Hall tidak dijelaskan tipe artisan memiliki berpotensi kreatif.

\section{SIMPULAN}

Berdasarkan hasil penelitian hasil tes dan wawancara kemampuan berpikir kreatif dalam memecahkan masalah matematika ditinjau dari tipe kepribadian siswa kelas IV MI Yasua Pilangwetan Kebonagung Demak yang telah dilakukan dan pembahasan yang telah dipaparkan peneliti, diperoleh kesimpulan bahwa: (1) Artisan, teridentifikasi pada aspek kelancaran, keluwesaan, keaslian, dan elaborasi cenderung cukup baik, tidak baik, kurang baik, dan baik. (2) Guardian, teridentifikasi pada aspek kelancaran, keluwesaan, keaslian, dan elaborasi cenderung kurang baik, tidak baik, tidak baik, dan kurang baik. (3) Idealist, teridentifikasi pada aspek kelancaran, keluwesaan, keaslian, dan elaborasi cenderung baik, tidak baik, kurang baik, cukup baik. (4) Rational, teridentifikasi pada aspek kelancaran, keluwesaan, keaslian, dan elaborasi cenderung sangat baik. Secara umum rational memenuhi keempat aspek kemampuan berpikir kreatif matematika, sedangkan tipe artisan, guardian, dan idealist tidak memenuhi keempat aspek kemampuan berpikir kreatif matematika.

\section{SARAN}

Hasil tersebut menyebutkan bahwa hanya subjek rational yang memenui aspek kemampuan berpikir kreatif matematika, oleh karena itu peneliti memberikan saran agar guru mata pelajaran matematika dalam membuat atau mengembangkan soal atau masalah dapat mempertimbangkan beberapa hal yang berkaitan dengan peningkatan kemampuan berpikir kreatif siswa. Siswa tipe aryisan, guardian, dan idealist diharapkan untuk memperbanyak latihan soal kelancaran, keluwesan, keaslian, dan elaborasi, selain itu guru harus mengetahui dan memahami tipe-tipe kepribadian siswa, sehingga mudah 
untuk menentukan model pembelajaran yang tepat, startegi dan metode yang efektif dan efiseien dalam pembelajaran di kelas.

\section{DAFTAR PUSTAKA}

Albar, W.F. 2015. Tingkat Berpikir Kritis Matematika siswa SMP kelas VII ditinjau dari Tipe Kepribadian dalam Setting Problem Based Kearning, Semarang: $\quad$ Fakultas Matematika dan Ilmu Pengetahuan Alam Universitas Negeri Semarang.

Ali, M. 2012. Ilmu Pendidikan Islam, Semarang: PKPI2 Universitas Wahid Hasyim.
Keirsey, D. 1998. Please Understand Me II. Carlsbad: Prometheus Nemesis Book Company.

Republik Indonesia. 2003. Undangundang Republik Indonesia Nomor 20 Tahun 2003 tentang Sitem Pendidikan Nasiuonal, Jakarta: Depdiknas.

Siswono, T. Y. E. 2015. Upaya Meningkatkan Kemampuan Berpikir Kreatif Siswa Melalui Pengajuan Masalah. Jurnal Pendidikan Matematika dan Sains, Tahun X, No.1., Yogyakarta: FMIPA UNY.

Wijaya, L. 2015. Analisis Kemampuan Berpikir Kreatif Matematis Ditinjau dari Tipe Kepribadian, Semarang: Universitas Negeri Semarang. 